Research.

\title{
The factors influencing audit quality and its impact upon judgement on materiality level
}

\author{
Ahmad Winanto \\ Politeknik Tunas Pemuda Tanggerang \\ ahmadwinanto85@gmail.com \\ Blasius Fembriyanto Trisno Saputro \\ Politeknik Bina Budaya Cipta Sukabumi \\ fembrixs@gmail.com \\ Received: August 12, 2019; Accepted: November 7, 2019; Published: December 31, 2019. \\ To cite this article: Winanto, Ahmad, Blasius Fembriyanto Trisno Saputro. (2019). The Factors Influencing Audit \\ Quality and its Impact upon Judgement on Materiality Level. The Accounting Journal of Binaniaga. 4 (2): 21-34. \\ doi: 10.33062/ajb.v4i2.339

\begin{abstract}
The purpose of this study is to determine profesionalism, professional ethics and experience on audit quality and effect of auditor upon judgement of materiality level. Data has been obtained by survey questionnaires, which is completed by auditors who work at Registered Public Accountants, started from junior up to partner level. The number of auditors of this study were 103 auditors from 16 Public Accounting Firm, period of January - May 2015. Data analyzed using Structural Equation Modelling (SEM) variance on (Partial Least Square). The result of this study has shown that professionalism and professional ethics have significant and positive influenced the auditor' judgment on materiality level. And audit quality has significantly and positively influenced the auditor' judgment on materiality level. Experience has not positively influenced audit quality and auditor' judgement on materiality level.
\end{abstract}

Keywords: Professionalism, experience, professional ethics, audit quality and auditor judgment on materiality level.

\section{Introduction}

This research is a development of the research done by Sukriah, et al.(2011), Futri and Juliarsa (2014). The differences of this research with the previous one refer to : 1) additional dependent variable of judgement on materiality and evaluation of independent variables of professionalism, experience and profesion ethics upon dependent variable of materiality level judgement (Herawaty and Susanto, 2009; Yen, 2012; Rachmawati, 2013 and Yunitasari, et al, 2014. And 2) additional of audit quality test upon judgement on materiality level (Trisnaningsih, 2010).

Based on the description above, it has determined specifically the problems of this research are as follows: (1) Is there any effect of professionalism upon audit quality?; 2) Is there any effect of experience upon audit quality? 3) Is there any effect of profesion ethics upon audit quality?; 4) Is there any effect of professionalism upon judgment on materiality level?; 5) Is there any effect of experiences upon judgement on materiality level?;6) Is there any effect of profesion ethics upon the judgement on materiality level? 


\section{Library Review}

\section{Description of the theory}

\section{Attribution Theory}

Attribution theory is describing the process of how we define someone's behavior, motive and reason. This theory refers to the description of to what extent someone is describing the reason of others behavior or his behavior which will be determined either by internal influencers such as traits, characters, attitude, etc. or by external influencers such as situation pressure or a certain circumstance which is influencing individual behavior (Luthans, 2006).

\section{Cognitive Dissonance Theory}

Referring to Festinger (1957) quoted in Wahyudi, et al. (2013) describing that cognitive dissonance is a discrepancy or a gap happened between two elements of cognitive which are not consistent causing psychological inconvenience. Cognitive refers to any kind of knowledge, opinion, beliefs, or self awareness or environmental awareness..

\section{Audit Quality}

Audit quality refers to the criteria standardization, or measurement quality related to the achievement using the applicable procedures. In Indonesia, quality control of audit quality has applied the standard of public professional accountant determined by the Indonesia Accountant Association (Trisnaningsih, 2010).

\section{Judgement on Materiality Level}

Materiality in accountancy is relative, it is quantitative value which is an important thing coming from some finance information of finance report for the user to make a decision(Frishkoff, 1979 quoted in Hastuti, et al. 2003) Role of materiality concept is to influence the quality and quantity of accountancy information required by auditors to make any decision related to the actual evidence.

\section{Professionalism}

Arens et al. (2011) defined professionalism is an individual responsibility to behave better rather than only following the Acts of the State and the applicable society regulations. Professionalism is also an element of motivation for the people to provide their best job performance.

\section{Experience}

Christiawan (2002) and Hafifah (2012) described that the more the task complexity given, the better the experience will be which will enhance his knowledge and insight. Gusti and Ali (2008),Futri and Juliarsa (2014) describing that auditor experience is recognizable from their experience to execute audit to check finance report either related to time consuming or quantity of the task executed.

\section{Profession Ethics}

Profession ethics is one of the factors influencing audit quality. Code of conduct is absolutely required to regulate public accountant executing their jobs (Fitri and Juliarsa, 2014) The reason why ethics is very important to be respected by professional agents is referred to public trust and requirement about service quality they provide. Nevertheless, auditors should have respected their professional ethics to make people trust for what they have been doing especially for the users of finance reporting. 


\section{Research Design}

Based on the theories above, a research design can be described as the following:

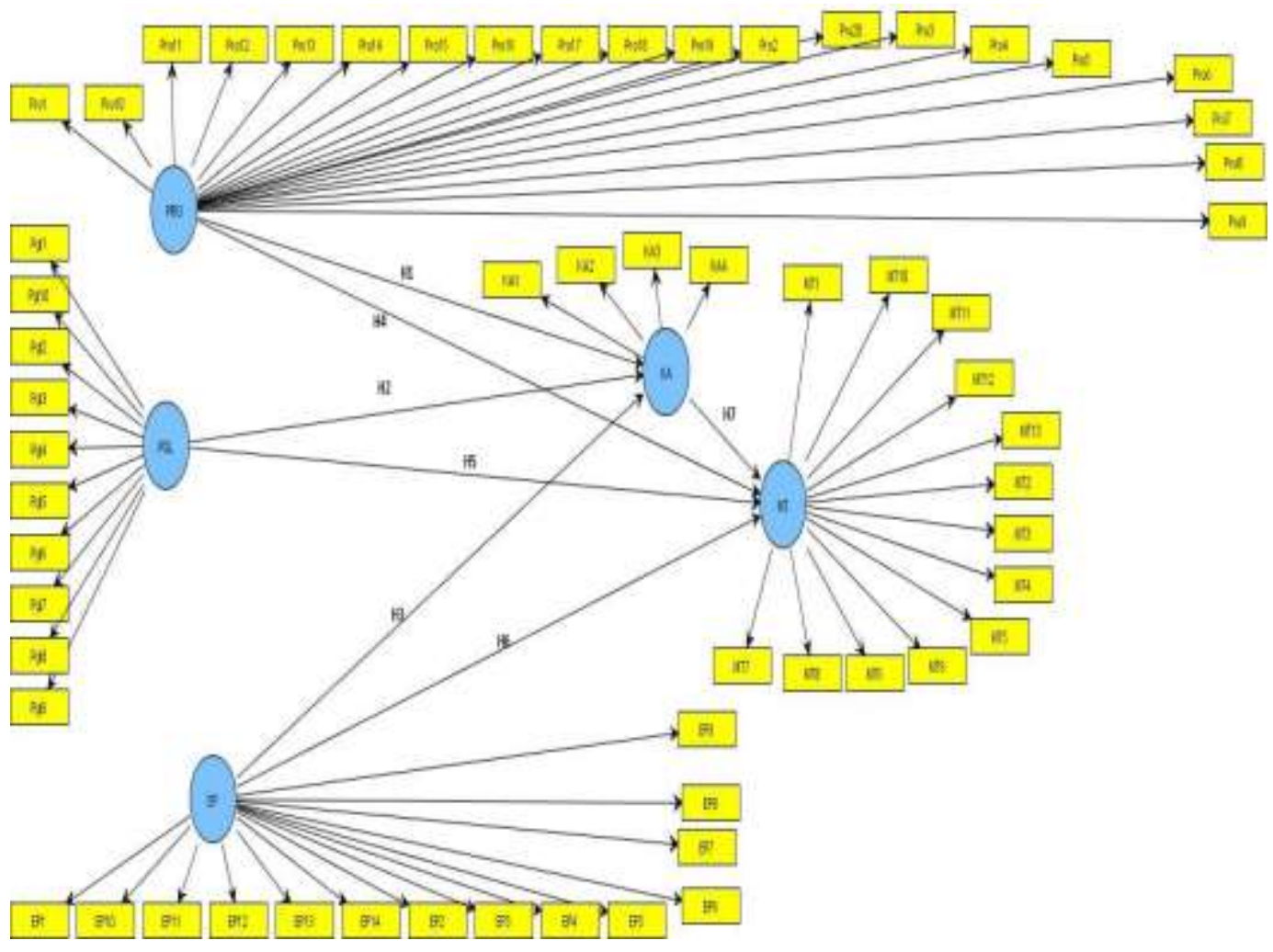

Research Method

\section{Type of the Research}

Is a research which aims to test the hypotheses about the effect of one or more variables (independent variables) upon other variable (dependent variable)(Herliansyah, 2013). This research is going to test the effect of latent independent variables of professionalism, experience and profesion ethics upon latent dependent variables of audit quality and judgement on materiality level.

\section{Variable Measurement}

\section{Dependent Variables}

a. Audit Quality

Variable of audit quality is measured by using the indicators developed by $\mathrm{De}$ Angelo (1981) quoted in Trisnaningsih (2010) which is consisting of 4 question items.

b. Judgement on Materiality Level.

Variable of Judgement on Materiality Level is measured by using the indicators developed by Hastuti, et al.(2003) quoted on Herawaty and Susanto (2009) consisting of 6 dimensions which is containing 13 items of question. 


\section{Independent Variables}

a. Professionalism

Professionalism variable has applied concept of Hastuti, et al.(2003) quoted in Herawaty and Susanto (2009) which is consisting of 5 dimensions to evaluate professionalism using 20 items of question.

b. Experience

Experience variable is measured by using the indicators developed by Futri and Juliarsa (2014) which containing 2 dimensions consist of 10 items of question.

c. Profession Ethics

Judgement on materiality level variable is measured by using the indicators developed by Futri and Juliarsa (2014) containing 5 dimensions which consist of 14 items of question.

\section{Variables Measurement}

All items of the question either latent independent variables or latent dependent variables are measured using interval scale of Likert which is 1 up to 5 . The responses will be scored as follows: 1) mostly disagreed, 2) disagreed, 3) neutral, 4) agreed, 5) mostly agreed.

\section{Population and Sample of the Research}

Population of this research are auditors who are working at Public Accountant Office (KAP) in Jakarta. Based on the directory book or KAP year 2013, there were 235 $\mathrm{KAP}$ (http://www.iapi.or.id/iapi/directory.php). From this population, the researcher is going to define the samples size using random sampling.

\section{Technics of Data Collection}

This research has applied primary data which is data collection technics using survey methods which is the questionnaires.

\section{Analysis Method}

Method of data analysis has applied descriptive statistics and Structural Equation Modelling (SEM) based on variance (Partial Least Square)

\section{1) Descriptive Statistics}

In this research, descriptive statistics is applied as analysis technics to describe or to provide respondent demographic information ( gender, age, job title, education, registered accountant and job experience)

2) Structural Equation Modelling (SEM) on variance basis (Partial Least Square)

Method of the research has applied Structural Equation Modelling (SEM) on variance basis (Partial Least Square). PLS is structural equation model (SEM) based on component or variance (variance).

1. Outer model:

a. Validation test: convergent validation test is to see the value of Loading Factor and Average Variance Extracted (AVE).

b. Reliability test: Measurement of internal consistency is shown on the value of Reliability Composite. Reliability composite value should have more than 0.7 .

2. Inner model:

Structural model is evaluated by using R-square for dependent construct and ttest as well as its sig.value coming up from structural parameter coefficient. 


\section{Result and Desription}

\section{Descriptive Statistics}

1. Distribution of the Research Instrument

Distribution of 160 questionnires and data collection was done in Januari May 2015. But only 120 questionnaires returned, however only 103 questionnaires could be processed. Since 160 questionnaires had been distributed and only 120 questionnaires had returned or it was about $75 \%$ of total questionnaires returned. Nevertheless, it has shown good result of a response rate.

Mostly the respondents were dominated by man about $66.2 \%$. They were about under 25 years old which was about $56.31 \%$, followed by the age of $25-35$ years which was $31.07 \%$. Their education mostly was college degree (S1) about $77.67 \%$. And they were junior auditors which was about $56.31 \%$ and senior auditors of $31.07 \%$ They had been working for less than 3 years the most which was $56.31 \%$ and followed by $3-5$ years about $31.07 \%$ However, most respondents had not got yet registered accountants which was $95.15 \%$.

2. Variable Description of the Research

When value of standard of deviation is less than mean value, however, mean value can be used as the representative of all data. Table above has shown mean value of Professionalism (PRO) of 70.05, mean value of Experience (PGL) of 35.64, mean value of Profesion Ethics (EP) of 50.87, mean value of Audit Qualit (KA) of 14.03 , mean value of Judgement on Materiality Level (MT) of 45.84 .

\section{Test of Model Appropriateness and Quality of Research instrument.}

1. Evaluation of Measuring Model or Outer Model.

a. Test of Constructs validity using Convergent Validity Test.

Convergent validity of measurement model using indicator reflection is evaluated based on the correlation between item score/component score estimated by PLS software. Individual indicator is valid if correlation value of more than 0.7 refers to construct (latent variable) being measured. However, at the beginning of the research about measurement scale development has indicated value of loading factor of 0.5 to 0.6 and considered acceptable. (Ghozali, 2012)

Result of convergent validity has resulted 3 (three) correlated indicators refers to the constructs having loading factor result (out loading) of less than 0.5 (not valid), and the researcher has to eliminate the indicator which is less than 0.5. Referring to PLS Algorithm result, it has indicated that all constructs which have gained loading factor value of $>0.7$ explaining that all construct indicators are valid. However, some indicators have gained loading factor of $>06$ and according to Hair et al.(2011) quoted in Ghozali (2012) it is still acceptable.

Besides of loading factor value, validity convergent test has to be done to see the value of Average Variance Extracted (AVE) that should have been more than 0.5. It has resulted Value of AVE for each variable ; Professionalism variable (PRO) of 0.401 , Experience variable (PGL) of 0.593 , Professsion Ethics variable (EP) of 0.487 , Audit Quality variable of 0.505 , and Judgement on Materiality Level (MT) of 0.418 .

Refers to AVE result, three variables are not in compliance with the standard. However, those variables are still acceptable because (1) data of the research is presented according to the actual circumstances: (2) this measurement has been just covering reliability construct: and (3) loading factor of each construct is in compliance with the standard. 


\section{b. Construct Validity Test using Dicriminant Validity.}

Instead of validity convergent test above, discriminant validity test of the model has been executed using reflective indicator measurement. Test has been done refers to cross loading value between indicator and the construct. Another method to evaluate discriminant validity is comparing each construct of quadrate root of average variance extracted $\sqrt{A V E}$ with the correlation of other

constructs. It is concluded that value of AVE quadrate root is bigger than AVE value or correlation of the constructs in this model. It has indicated that each construct is having good discriminant validity value.

c. Reliability test using Composite Reliability.

Instead of validity test of the construct, construct reliability test is measured by composite reliability. The construct is declared reliable if the value of composite reliability is more than 0.7 . Value of composite reliability for all constructs are good due to the value of more than 0.7 , however, it is concluded that all construct indicators are reliable or in compliance with reliability test.

2. Structural Model Test or Inner Model

In order to evaluate structural model or inner model, it can refer to the value of $\mathrm{R}$-Square $\left(\mathrm{R}^{2}\right)$ and $\mathrm{Q}$-Square $\left(\mathrm{Q}^{2}\right)$ of each latent endogen variable. $\mathrm{R}$-Square result of Audit Quality construct (KA) of 0.648 is still within moderate. This value has interpreted that Professionalism variable (PRO), Profession Ethics (EP) are able to describe $64.8 \%$ of Audit Quality variable. However, the remaining of $35.2 \%$ is described by other variables which are not in this model. R-square result of judgement on materiality level (MT) of 0.914 is within a strong category describing that construct of judgement on materiality level (MT) can be explained by Profesionalism variable (PRO), Experience variable (PGL), Profession Ethics (EP) which is $91.4 \%$, but $8.6 \%$ is explained by other external variables being studied. Qsquare has been executed to measure how good the observation value provided by this model and to measure the related parameter. And it has resulted the following equation:

$\mathrm{Q}^{2}=1-\left(1-\mathrm{R}_{1}^{2}\right)\left(1-\mathrm{R}_{2}{ }^{2}\right)$, where $\mathrm{R}_{1}{ }^{2}=\mathrm{R}^{2}$ audit quality and $R_{2}{ }^{2}=R^{2}$ judgement on materiality level. And the value are as the following:

$\mathrm{Q}^{2}=1-(1-0,648)(1-0,914)$

$Q^{2}=1-(0,352)(0,086)$

$\mathrm{Q}^{2}=1-0,030$

$\mathrm{Q}^{2}=0,970$

Refers to the result, it has indicated Q2 of 0.970 explaining that the value of varied data of the reseach can be explained by structural model developed in this research which is $97 \%$. Based on this result, structural model is having goodness of fit or quite good.

\section{Hypotheses Test}

This research has 7 hypotheses to answer all the problems occurred. Hypotheses 1 to $3(\mathrm{H} 1$ to $\mathrm{H} 3)$ are to test significant effect of Profesionalism variable (PRO), Experience variable (PGL), Profession Ethics variable (EP) upon Audit Quality (KA) Nevertheless, Hypotheses 4 to $6(\mathrm{H} 4$ to $\mathrm{H} 6)$ are to test the significant effect of Profesional variable (PR), Experience variable (PGL), Profesion Ethics variable (EP) and Hypotheses $7(\mathrm{H} 7)$ is to test Audit Quality variable upon judgement on materiality level. By applying PLS, it has indicated inner loading result on parameter coefficient value is having sig.value of t-statistics indicating that all the hypotheses are having significant influences which is mentioned on the table below.

Ahmad Winanto and Blasius Fembriyanto Trisno Saputro. The Factors Influencing Audit Quality and its Impact upon Judgement on Materiality Level 


\section{Table of Inner Loading}

\begin{tabular}{|c|c|c|c|c|c|}
\hline Variabel & original sample estimate & mean of subsamples & Standard deviation & T-Statistic & Kesimpulan \\
\hline PROF $>>$ KA & 1.098 & 1.088 & 0.175 & 6.272 & Signifikan \\
\hline PGL $>>K A$ & -0.595 & -0.561 & 0.164 & 3.618 & Signifikan \\
\hline$E P->K A$ & 0.297 & 0.299 & 0.069 & 4.285 & Signifikan \\
\hline PROF -> MTR & 0.696 & 0.648 & 0.114 & 6.093 & Signifikan \\
\hline PGL -> MTR & -0.347 & -0.294 & 0.082 & 4.238 & Signifikan \\
\hline EP $\rightarrow$ MTR & 0.198 & 0.194 & 0.046 & 4.263 & Signifikan \\
\hline KA $\rightarrow$ MTR & 0.471 & 0.468 & 0.072 & 6.503 & Signifikan \\
\hline
\end{tabular}

Source : data processed by SmartPLS.

\section{Description}

Description of hypotheses test results are in compliance with the hypotheses offered at the beginning of the research which can be explained as the following:

\section{H1. Profesionalisme has positively affected Audit Quality}

Result of analysis has indicated that Professiionalisme has affected positively upon Audit Quality. It is shown on the table 5.0 describing that tcount value of 6.272 which is bigger than table of $1.96(6.272<1.96)$. It has explained that professionalism can influence Audit Quality. Nevertheless Hypothesis (H1) is accepted.

This research is in line with the research of Mayasari (2012) confirmed by research of Baotham(2007), Ussahawanitchakt (2008) declared that professionalism has affected Audit Quality. Profesionalism means that Auditor can not be intimidated by anyone and is unable underpressured by anybody who wants to interfere his/her opinion and attitude. The higher the profesionalisme, the better the audit quality will be. It is happened due to the respondents have had good professionalism attitude. During the inspection, the respondent has to be professional, he cannot be intimidated by anybody. As a matter of fact, it could be probably some auditors might be doing some deviations against audit standard and code of ethics.

2. H2. Experience has positively affected Audit Quality.

Result of the test has described that Expereience has affected significantly and negatively Audit Quality. This result is depicted on table 5.10 that tcount value of 3.618 which is bigger than table $1.96(3.618>1.96)$ Negative value of Parameter Coefficient has indicated that the more the experience of an auditor is, the higher the Audit Quality will be. Since the result of the research has had negative parameter coefficient but the hypothesis offered is positive, Nevertheless H2 is rejected, even though $t_{\text {count }}$ value of 3.618 which is bigger than table $1.96(3.618>1.96)$

This result is not in compliance with the research of Sukriah, et al. (2013) determined that experience has influenced positively Audit Quality. It has happened due to most repondents are junior auditors where their complexity of the tasks is relatively still low, and the ability to evaluate risk of audit is low too. However, it could make the auditors unable detecting any fraud happened. As a matter of fact, auditor team has been supervising and guiding their job. So that, junior auditors will have better risk judgement. The better the audit risk evaluation is, the better the auditor competency will be to detect any fraud. Therefore, audit quality can be maintained as required. Nevertheless, result of the research had shown that Experience has negatively and significantly affected Audit Quality is acceptable. 
3. H3. Profession Ethics has positively affected Audit Quality.

Result of the research has indicated that Profession Ethics has signicantly and positively affected Audit Quality. It is depicted on the table 5.10 identifying value of $t_{\text {count }}$ of 4.285 which is bigger than table of $1.96(4.285>1.96)$. The bigger the profession ethics will create better audit quality. Therefore, $(\mathrm{H} 3)$ is accepted.

This result is getting along with research of Futri and Juliarsa (2014) and Hutabarat (2012) indicated that Profession Ethics had positively influenced Audit Quality. Nevertheless, the bigger the auditor ethics is happened, the better the audit quality will be.

4. H4. Professionalism has positively affected judgement on materiality level

Result of the research has identified that professionalism has significant and positive affected judgment on materiality level. Table 5.10 has depicted value of tcount 6.093 which is bigger that table of $1.96(6.093>1.96)$ The bigger the professionalism, the higher the judgment on materiality level would be. Nevertheless Hypothesis $(\mathrm{H} 4)$ is accepted.

Result of this research is in compliance with the research of Herawati and Susanto (2009) and Febrianty (2012). Sinaga and Isgiyarta (2012), Lestari and Utama (2013), Kurniawanda (2013), Muhammad (2013) who described that professionalism had significantly influenced the judgement on Materiality level. It happened due to the respondents had had good professionalism which increased the judgement on materiality level.

5. H5. Experience has positively influenced Judgement on Materiality Level.

Result of the research has described that Experience has had significant and negative influences on Judgment on Materiality Level. Table 5.0 has shown value of tcount of 4.238 which is bigger that table of 1.96 (4.238 $>1.96$. Negative value of Parameter Coefficient has depicted that the better the experience of an auditor, the better the judgement on materiality level would be. Since parameter coefficient is negative, but hypothesis offered is positive, hypothesis (H5) is rejected even though $t_{\text {count }}$ of 4.238 is bigger that table of $1.96(4.238>1.96)$

This result is not getting along with the research of Herawati and Susanto (2009) determined that experienced auditors would produce better knowledge over judging material level. It has happened due to mostly the respondents are still junior auditors who has been working for only not more than 3 years.. Of course, it is influencing their detection upon the judgement on materiality level. Having low experience of the auditors, it has caused low complexity of auditors' task reflecting to low capability to evalue the auditing risk which is far from the expectation. Nevertheless, they are not in the position to judge materiality level properly. Actually, the auditing team has been supervising junior auditor's job, so that junior auditors will be having more understanding to value the risk which is better execution. Evaluating better audit risk will create auditor competency to produce better judgement on materiality level. Nevertheless, result of the research described that ecperience has negatively and significantly influenced judgement on materialilty level.

6. H6. Profesion Ethics has affected Judgement on Materiality Level.

Result of the research had identified that Profession Ethics has significantly and positively affected Judgement on Materiality Level. Value of tcount of 4.263 is bigger than table of $1.96(4.263>1.96)$. The more the profession ethics of an auditor, the bigger the judgement on materiality level will be. So that, hypothesis (H6) is accepted 
This research is in accordance with the research of Herawati and Santoso (2009) determined that auditors who had been respecting profession ethics would produce independent and objective judgement on materiality level. Nevertheless, it is getting along with hypothesis $\mathrm{H} 6$.

7. H7. Audit Quality has positively affecting Judgement on Materiality Level.

Result of the research has identified that Audit Quality has influenced Judgement on Materiality Level significantly and positively. Table 5.10 mentioned value of table of 6.503 bigger than table of $1.96(6.503>1.96)$. It has been explaining that Audit Quality can increase Judgement on Materiality Level . Nevertheless, hypothesis $(\mathrm{H} 7)$ is accepted.

This research is in compliance with the research of Trisnaningsih (2010) describing that Public Accountant will be able to recognize the quality of its audit refers to clients satisfaction. However, a public accountant should have improved its audit quality. Clients satisfaction will create trustworthy of the competency of public accountant. In order to reach best quality achievement, materiality level should have to be respected.

Based on the result of hypotheses above, it has concluded that 5 (five) hypotheses accepted are $\mathrm{H} 1, \mathrm{H} 3, \mathrm{H} 4, \mathrm{H} 6$ and $\mathrm{H} 7$. However another hypotheses are rejected, eventhough $t_{\text {count }}$ is significant.

Based on the result above, the writer will analyze direct and indirect analyses to see if path of this research should have gone through intervening variable or direct intervariables. And refers to the analysis above, it is describing that profesionalisme variable has affected judgement on materiality level of 1.213 which is bigger than the direct analysis of 0.696 . So that, intervening variable is required, which is through audit quality variable.

As Experience variable upon judgement on materiality level has resulted total of the effect value of -0.627 which is less than direct effect value of -0.347 , therefore, it would be better if experience variable upon judgement on materiality level variable should not have gone through intervening variable. And the effect of intervening variable of audit quality could be neglected.

But the effect of Profession Ethics(EP) variable upon judgement on materiality level (MTR) has indicated total value of the effect of 0.338 which is bigger that direct effect value of 0.198 . Nevertheless, intervening variable is required which is Audit Quality variable $(K A)$

\section{Conclusion and Suggestions}

\section{Conclusion}

1. Professionalism has positively affected audit quality. It has identified that auditors could not be intimidated by other people who wanted to influence their attitude and opinion. The higher the professionalism, the better the audit quality is.

2. The Experience has not positively affected audit quality. The more the experience of the auditor is not able to improve audit quality.

3. Profession Ethics has positively affected audit quality. Best audit ethics will influence audit quality.

4. Professionalism has positively affected judgment on materiality level. The better the professionalism, the higher judgement on materiality level will be.

5. Experience has negatively affected judgement on materiality level. The better the experience, the less the judgement on materiality level will be. 
6. Profession Ethics has positively affected judgement on materiality level. Having best profession ethics, the result of auditor in judging the materiality level will be more independent and objective.

7. Audit quality has positively affected judgement on materiality level. An auditor should have been able to improve his audit quality, because Client satisfaction upon his audit service will produce his client trustworthy upon public accountant. In order to achieve good quality, judgement on materiality level is required to be respected.

\section{Implication}

Referring to the result of this research, the researcher is expecting that this research will be usefull for all the parties as the references for academicians. For further research, it is expected to be able to enlarge and develop this research furthermore.

\section{Suggestions}

This research has some limitations, therefore, future researches should have included other variables influencing audit quality such as independency and accountability (Saripudin, et al. 2012) and some variables that are affecting judgement on materiality level such as knowledge to detect any frauds. (Herawati and Susanto, 2009).. And to involve total of the samples and more respondents who are having experience more than 5 years.

\section{References}

Arens, A. A. \& Loebbecke, J. K. (2011). Auditing, an Integrated Approach (7thed). Upper Saddle River, New Yersey: Prentice-Hall, Inc.

Badjuri, A. (2012). Analisis faktor-faktor yang mempengaruhi kualitas hasil pemeriksaan audit sektor publik (Studi empiris pada BPKP perwakilan jawa tengah). Dinamika Akuntansi, Keuangan dan Perbankan, Vol. 1, No. (2). Hal: 120 - 135.

Baotham, S. (2007). Effects of Professionalism on Audit Quality and Self-image of CPAs in Thailand, International Journal of Bussiness Strategy.

Desiana. (2012). Pengaruh Profesionalisme, Pengetahuan mendeteksi kekeliriuan dan Etika Profesi Terhadap Pertimbangan Tingkat Materialitas Audit Oleh Auditor KAP Di Surabaya. Jurnal Berkala IImiah Mahasiswa Akuntansi Vol. 1, No. (1).

Entuu, R. E. F., Sondakh, J. J dan Ventje I. (2013). Pengaruh Profesionalisme Auditor, Kualitas Audit, Etika Profesi Auditor, dan Pengalaman Auditor Terhadap Pertimbangan Tingkat Materialitas Dalam Pemeriksaan Laporan Keuangan Pada Badan Pemeriksa Keuangan Republik Indonesia Perwakilan Sulawesi Utara. Jurnal Riset Akuntansi dan Auditing Maksi, Universitas Samratulangi, Sulawesi Utara.

Febrianty. (2012). Pengaruh Profesionalisme Auditor Terhadap Pertimbangan Tingkat Materialitas Audit Atas Laporan Keuangan. Jurnal Ekonomi dan Informasi Akuntansi Vol. 2, No.(2).

Futri, P. S, dan Juliarsa, G. (2014). Pengaruh Independensi Profesionalisme ,tingkat pendidikan, etika profesi, pengalaman dan kepuasan kerja Auditor Terhadap kualitas audit pada kantor akuntan publik di bali. E-Jurnal Akuntansi Universitas Udayana Vol. 8, No.(1). Pg:41-58.

Ghozali, I. (2008). Structural Equation Modeling, Metode Alternatif dengan Partial Least Square (edisi 2). Semarang: Badan Penerbit Universitas Diponegoro.

Ahmad Winanto and Blasius Fembriyanto Trisno Saputro. The Factors Influencing Audit Quality and its Impact upon Judgement on Materiality Level 
Ghozali, I. (2012). Aplikasi Analisis Multivariate dengan Program SPSS 20 (edisi VI). Semarang: Badan Penerbit Universitas Diponegoro.

Gusti, M dan Ali, S. (2008). Hubungan Skeptisme Profesional auditor dan situasi etika, pengalaman serta keahlian audit dengan ketepatan pemberian opini auditor oleh akuntan public. Simposium Nasional Akuntansi XI.

Hafifah dan Fitriany. (2012). Pengaruh Beban Kerja, Pengalaman Audit Dan Tipe Kepribadian Terhadap Skeptisme Profesional Dan Kemampuan Auditor Dalam Mendeteksi Kecurangan, Simposium Nasional Akuntansi.

Halim, Abdul. 2008. Auditing I (Dasar-Dasar Audit Laporan Keuangan), Edisi Ketiga. Yogyakarta: UPP AMP YKPN.

Herawaty, A. Dan Sutanto, Y. K. (2009). Profesionalisme, Pengetahuan Akuntan Publik dalam mendeteksi kekeliruan, Etika Profesi dan pertimbangan tingkat materialitas. Jurnal Akuntansi dan Keuangan,II. No.(1) Mei,13-20.

Herliansyah, Y. dan llyas, M. (2006). Pengaruh Pengalaman Auditor Terhadap Penggunaan Bukti Tidak Relevan Dalam Auditor Judgment. Simposium Nasional Akuntansi IX. Padang.

Herliansyah, Y. (2013). Pedoman Penyusunan Tesis Dan Prosedur Akademik (edisi 2). Jakarta: Program Pascasarjana Program Studi Magister Akuntansi.Universitas Mercubuana.

Hutabarat, G. (2012). Pengaruh Pengalaman, Time Budget Pressure, dan Etika Auditor terhadap Kualitas Audit. Jurnal IImiah ESAI. Volume 6 Nomor 1.

Institut Akuntan Publik Indonesia. (2011). Standar Profesional Akuntan Publik. Jakarta: Salemba Empat.

Institut Akuntan Publik Indonesia. (2013). Directory Kantor Akuntan Publik 2013. Diakses pada 10 Oktober 2014 dari World Wide Web: http://www.iapi.or.id/iapi/download/Directory2013/Jakarta.pdf.

Jogiyanto. (2007). Sistem Informasi Keperilakuan. Yogyakarta: Andi Offset.

Jogiyanto. (2009). Konsep dan Aplikasi PLS (Partial Least Square) Untuk Penelitian Empiris. Yogyakarta: BPFE.

Keune, M. B dan Johnstone, K. M. (2012). Materiality judgement and the resolution of detected misstatement: the role of manager, auditor dan audit committees. The Accounting Review Vo. 87,No.(5)American Accouniting Association.

Kurniawanda, A.M. (2013). Pengaruh Profesionalisme Auditor Dan Etika Profesi Terhadap Pertimbangan Tingkat Materialitas. E-Jurnal BINAR AKUNTANSI. Vol. 2 No (1).

Kovinna, F., dan Betri. (2014). Pengaruh Independensi, pengalaman kerja, kompetensi dan etika auditor terhadap kualitas audit. Diakses tanggal 10 Oktober 2014 dari World Wide Web: http://eprints.mdp.ac.id/1152/1/Jurnal\%20Fransiska\%20Kovinna\%20\%28201021 $\underline{0097 \% 29 . p d f}$ 
Lestari, N. M. A dan Utama, I. M. K. (2013). Pengaruh profesionalisme, pengetahuan mendeteksi kekeliruan,pengalaman, etika profesi pada pertimbangan tingkat materialitas. E-Jurnal Akuntansi Universitas Udayana 5.(1),112-129.

Luthans, F. (2006). Perilaku Organisasi. Edisi Sepuluh. Penerbit Andi. Yogyakarta

Muhammad, E. (2013). Pengaruh Profesionalisme, Pengetahuan dan, Etika Profesi terhadap pertimbangan tingkat materialitas pemeriksaan laporan keuangan. JAFFA Vol. 1 No.(1), 1-14.

Mayasari, I. (2012). Pengaruh Profesionalisme auditor dan masa perikatan audit terhadap kualitas audit. (Penelitian pada kantor akuntan publik di bandung yang terdaftar di BAPEPAM-LK. Universitas Komputer Indonesia.

Marito, E. R., Anugerah, R.,dan Idrus. R. (2013). Profesionalisme, Pengetahuan Akuntan Publik dalam mendeteksi kekeliruan, Etika Profesi dan pertimbangan tingkat materialitas. The Second National Conference UKWMS, Universitas Trisaksi, Jakarta.

Nugraha, M. E. (2012). Pengaruh Independensi, Kompetensi dan Profesionalisme terhadap kualitas audit. Jurnal IImiah Mahasiswa Akuntansi Unika Widya Mandala.

Rachmawati, Y., Darwanis \& Bakar, U. (2013). Pengaruh Resiko Audit, Pengalaman dan Komplesitas Dokumen audit terhadap pertimbangan audit. (Studi pada auditor Kantor BPK-RI Perwakilan Aceh). Jurnal Akuntansi Pascasarjana Universitas Syiah Kuala Vol.2 No.(1),91-102.

Ríos-Figueroa, C. B \& Cardona, R. J. (2013). Does experience affect auditors' professional judgment? evidence from puerto rico. Accounting \& Taxation Vol.5 No.(2).

Sabrina, K., dan Januarti, I. (2012). Pengaruh Pengalaman, Keahlian, Situasi Audit,Etika dan Gender Terhadap Ketepatan Pemberian Opini Melalui Skeptisme Profesional Auditor ( Studi Kasus pada KAP Big Four di Jakarta) Jurnal Sistem Informasi, Etika dan Auditing SNAXV.

Saripudin, N. H dan Rahayu. (2012). Pengaruh Independensi,Pengalaman,Due Professional Care dan Akuntabilitas Terhadap Akutanbilitas Terhadap Kualitas Audit. E-Jurnal Binar Akuntansi, Vol. 1, No. (1).

Samsi, N., Riduan, A dan Suryono, B. (2013). Pengaruh Pengalaman Kerja, Independensi, Dan Kompetensi Terhadap Kualitas Audit: Etika Auditor Sebagai Variabel Pemoderasit. Jurnal IImu dan Riset Akuntansi, Vol. 1, No. (2).

Suraida, I. (2005). Pengaruh Etika, Kompetensi, Pengalaman Audit dan Risiko Audit Terhadap Skeptisisme Profesional Auditor dan Ketepatan Pemberian Opini Akuntan Publik. Sosiohumaniora, Vol.7, No.3, 186-202.

Sukriah I.,Akram,dan Inapity B.I. (2011). Pengaruh Pengalaman Kerja, Independensi, Obyektifitas, Integritas dan Kompetensi Terhadap Kualitas Hasil Pemeriksaan. Diakses pada 19 November 2014 dari World Wide Web: https://smartaccounting.files.wordpress.com/

Sinaga, M., dan Isgiyarta J. (2012). Analisis Pengaruh Profesionalisme Terhadap Tingkat Materialitas Audit Dalam Proses Pengauditan Laporan Keuangan. Diponegoro Journal Of Accounting, Vol. 1, No. (2).

Ahmad Winanto and Blasius Fembriyanto Trisno Saputro. The Factors Influencing Audit Quality and its Impact upon Judgement on Materiality Level 
Trianingsih, S. (2010). Profesionalisme Auditor Kualitas Audit dan Tingkat Materialitas Dalam Pemeriksaan Laporan Keuangan. Jurnal Maksi Universitas Pembangunan Nasional Veteran, Vol. 10, No.(2), Jawa Timur.

Ussahawanitchakit, P. (2008). Relationship Quality, Profesionalism, and Audit Quality: Empirical Study of Auditors in Thailand. International Journal of Bussiness Strategy, Thailand.

Wahyudi, D. P., Nur, E., dan Saidi., J. (2013). Hubungan Etika Profesi, Keahlian, Pengalaman, Dan Situasi Audit Dengan Ketepatan Pemberian Opini Dalam Audit Laporan Keuangan Melalui Pertimbangan Materialitas Dan Skeptisisme Profesional Auditor.

Yen, A. C. (2013). The Effect of Early Career Experience on Auditors' Assessments of Error Explanations in Analytical Review. Behavior Research In Accounting Vol.24 No.(2), pg:211-229. American Accounting Association.

Yunitasari, P. I., Adiputra, I. M. P dan Sujana, E. (2014). Pengaruh Professional Judgment Auditor, Independensi Dan Pengalaman Kerja Terhadap Pertimbangan Tingkat Materialitas Dalam Proses Audit Laporan Keuangan (Studi Kasus pada Auditor Badan Pengawasan Keuangan dan Pembangunan (BPKP) Perwakilan Provinsi Bali). E-Jurnal S1 Akuntansi, Universitas Pendidikan Ganesha, Bali. 
The Accounting Journal of BINANIAGA Vol. 04, No. 02, December 2019 p-ISSN: $2527-4309$, e-ISSN: $2580-1481$

$5^{\text {th }}$ Accreditation Rating: January 14, 2019 - January 13, 2024

This page intentionally be emptied.

Ahmad Winanto and Blasius Fembriyanto Trisno Saputro. The Factors Influencing Audit Quality and its Impact upon Judgement on Materiality Level 